\title{
Monoculture and mixture-planting of non-native Douglas fir alters species composition, but promotes the diversity of ground beetles in a temperate forest system
}

\author{
Peter Kriegel ${ }^{1}$ (D) - Dragan Matevski ${ }^{2} \cdot$ Andreas Schuldt $^{2}$ (D)
}

Received: 7 September 2020 / Revised: 11 January 2021 / Accepted: 9 March 2021 /

Published online: 23 March 2021

(C) The Author(s) 2021

\begin{abstract}
Planting non-native tree species, like Douglas fir in temperate European forest systems, is encouraged to mitigate effects of climate change. However, Douglas fir monocultures often revealed negative effects on forest biota, while effects of mixtures with native tree species on forest ecosystems are less well understood. We investigated effects of three tree species (Douglas fir, Norway spruce, native European beech), on ground beetles in temperate forests of Germany. Beetles were sampled in monocultures of each tree species and broadleafconifer mixtures with pitfall traps, and environmental variables were assessed around each trap. We used linear mixed models in a two-step procedure to disentangle effects of environment and tree species identity on ground beetle abundance, species richness, functional diversity and species assemblage structure. Contradictory to our expectations, ground beetle abundance and functional diversity was highest in pure Douglas fir stands, while tree mixtures showed intermediate values between pure coniferous and pure beech stands. The main drivers of these patterns were only partially dependent on tree species identity, which highlights the importance of structural features in forest stands. However, our study revealed distinct shifts in assemblage structure between pure beech and pure Douglas fir stands, which were only partially eased through mixture planting. Our findings suggest that effects of planting non-native trees on associated biodiversity can be actively modified by promoting beneficial forest structures. Nevertheless, integrating non-native tree species, even in mixtures with native trees, will invariably alter assemblage structures of associated biota, which can compromise conservation efforts targeted at typical species composition.
\end{abstract}

Keywords Exotic species · Pseudotsuga menziesii · Functional diversity · Insects · Microhabitats $\cdot$ Mixed-species forestry

Communicated by Nigel E. Stork.

This article belongs to the Topical Collection: Forest and plantation biodiversity.

Peter Kriegel

peter.kriegel@uni-wuerzburg.de

1 Field Station Fabrikschleichach, Biocenter, University of Würzburg, Glashüttenstr. 5, 96181 Rauhenebrach, Germany

2 Forest Nature Conservation, University of Göttingen, Büsgenweg 3, 37077 Göttingen, Germany 


\section{Introduction}

Human impact is increasingly altering ecosystems worldwide, with wide-ranging consequences for biodiversity and ecosystem services (Cardinale et al. 2012; Dirzo et al. 2014). Studies have reported noticeable declines in the abundance and local species richness of both vertebrates and invertebrates (Hallmann et al. 2017; Rosenberg et al. 2019; Klink et al. 2020). Although such declines are often particularly pronounced in agricultural systems with high land use intensity, recent research has shown that biodiversity loss is also happening in forests (Seibold et al. 2019). Reasons for declining forest biodiversity are less well understood for European forests, where forest management in many cases has shifted towards more nature-oriented practices over the last decades (Borrass et al. 2017; Gustafsson et al. 2020). Nevertheless, a scarcity of key resources, such as deadwood, and extensive monoculture planting of tree species outside of their natural range might have contributed to the observed patterns (Hilmers et al. 2018; Ampoorter et al. 2020).

Despite positive trends towards more nature-friendly management, threats to biodiversity may persist in the future. Reasons for this include the promotion of potentially climatically better adapted, non-native tree species due to climate change (Bindewald et al. 2019). Such non-native tree species are often characterized by an impoverished associated biodiversity (Kennedy and Southwood 1984) and their increasing use in many regions has spurred a wealth of studies investigating their impact on native biodiversity (e.g. Finch and Szumelda 2007; Irwin et al. 2014; Schuldt and Scherer-Lorenzen 2014; Oxbrough et al. 2016; Matevski and Schuldt 2020). These studies often revealed locally negative effects of non-native tree species on the abundance, composition and species richness of forest biota (e.g. Finch and Szumelda 2007; Schuldt and Scherer-Lorenzen 2014). In Central Europe, particular attention has been paid to North American Douglas fir (Pseudotsuga menziesii), which is considered one of the most important tree species to address the economic challenges imposed by climate change in this region (Schmid et al. 2014). Previous studies have shown that Douglas fir monocultures can have lower arthropod biomass (Finch and Szumelda 2007; Schuldt and Scherer-Lorenzen 2014), bird activity (Gossner and Utschick 2004), and microbial biomass (Lu and Scheu 2020), compared to stands of native tree species. However, other taxa were less affected (e.g. crown-dwelling beetles; see Gossner and Simon (2002)) or even benefitted from Douglas fir stands (e.g. vascular plants, which may benefit from light availability and favourable soil conditions), especially when compared to the influence of Norway spruce (Picea abies) (Schmid et al. 2014), another coniferous species planted outside of its native range throughout larger parts of Europe. Moreover, potential negative effects of non-native tree species on biodiversity might be attenuated when planted in lower mixture proportions together with native tree species (Oxbrough et al. 2016). Tree species mixtures are considered an important option to adapting forests to changing climate (Ammer 2019), and mixtures of native and non-native tree species might therefore be a way to combine economic demands and biodiversity conservation in an integrated fashion. However, our current knowledge base for a clear understanding of the ecological consequences of mixing non-native and native tree species is still limited for many of the most relevant species, such as Douglas fir (Schmid et al. 2014). Moreover, few studies to date have looked at the functional diversity of associated biota in this context (e.g. Gallé et al. 2018; Martello et al. 2018), although this component of biodiversity is key to understanding how the ecological roles of assemblages are altered by human impact on ecosystems (Cardinale et al. 2012). 
Here, we test how pure stands and two-species mixtures of three tree species varying in their degree of naturalness in Central European forests (non-native Douglas fir, Norway spruce planted outside its natural range, European beech, Fagus sylvatica, as the native tree species dominating under natural conditions) affect the abundance, species richness, functional diversity and species assemblage structure of ground beetles (Coleoptera: Carabidae). Our study was conducted on 20 study plots at four study sites in different regions of northern Germany. Ground beetles are a species-rich and well-studied group of arthropods sensitive to small-scale environmental conditions such as microclimate and habitat structure (Thiele 1977; Butterfield et al. 1995; Cameron and Leather 2012), which are altered by tree species composition. They support distinct communities in different habitats (Thiele 1977), thus making them well-suited indicators of habitat quality and targets for biodiversity conservation. We hypothesized that i) ground beetle abundance, species richness and functional diversity is lower in coniferous stands than in beech stands, as we expect greater microhabitat variability in beech stands, due to more spacious litter layer and higher availability of deadwood (e.g. Koivula et al. 1999). Negative effects of conifers compared to deciduous trees on ground beetle species richness and abundance were previously shown for other forest types (Elek et al. 2001; Barsoum et al. 2014; Oxbrough et al. 2016). Furthermore, we expect particularly strong negative effects of Douglas fir, as it is least associated with the native fauna. Negative effects of non-native Douglas fir have been shown for other epigeic arthropods (Finch and Szumelda 2007; Schuldt and Scherer-Lorenzen 2014), which might reduce prey availability for predatory arthropods such as ground beetles. However, we hypothesized that ii) mixtures with native European beech attenuate negative effects of admixing either of the two conifer species and might even lead to highest diversity due to the mixing of functionally very dissimilar tree species.

\section{Material and methods}

\section{Study area and sampling design}

Our study was conducted at four temperate forest sites in Lower Saxony, Germany ('Harz' (10.39707,51.77015), 'Dassel' (9.704126,51.72592), 'Winnefeld' (9.572035,51.66449), and 'Nienover' $(9.529744,51.69858)$ (Fig. 1). All study sites are in the transition from Maritime to Continental climate (mean annual temperature $6.8{ }^{\circ} \mathrm{C}$ in Harz and $7.4{ }^{\circ} \mathrm{C}$ on the other sites and mean annual precipitation $1397 \mathrm{~mm}$ in Harz and $1119 \mathrm{~mm}$ on the other sites (DWD 2018). Occurring bedrock on sites varies, with greywacke and argillaceous schist formations in Harz and lime- and sandstone formations on all other sites (NIBIS 2018). At each site, five study plots of $50 \mathrm{~m} \times 50 \mathrm{~m}$ representing five different stand types were established: (1) pure Douglas-fir (Pseudotsuga menziesii), (2) pure European beech (Fagus sylvatica), (3) pure Norway spruce (Picea abies), (4) mixture of European beech and Douglas-fir, and (5) mixture of European beech and Norway spruce. Distances between plots within sites ranged from minimal $88 \mathrm{~m}$ to $\max 3042 \mathrm{~m}$ with a mean distance of $1021 \mathrm{~m}$. Detailed information about stand characteristics of all study plots are displayed in Table S1 in the supplementary material. All studied stands were managed uniformly by the Lower Saxony state forest enterprise.

Ground beetle sampling took place between 23rd of March and 1st of September 2019. At each study plot 12 pitfall traps were placed in a grid of $3 \times 4$ with $10 \mathrm{~m}$ distance among traps. Traps consisted of transparent plastic cups with an upper diameter of $9.4 \mathrm{~cm}$ and a 

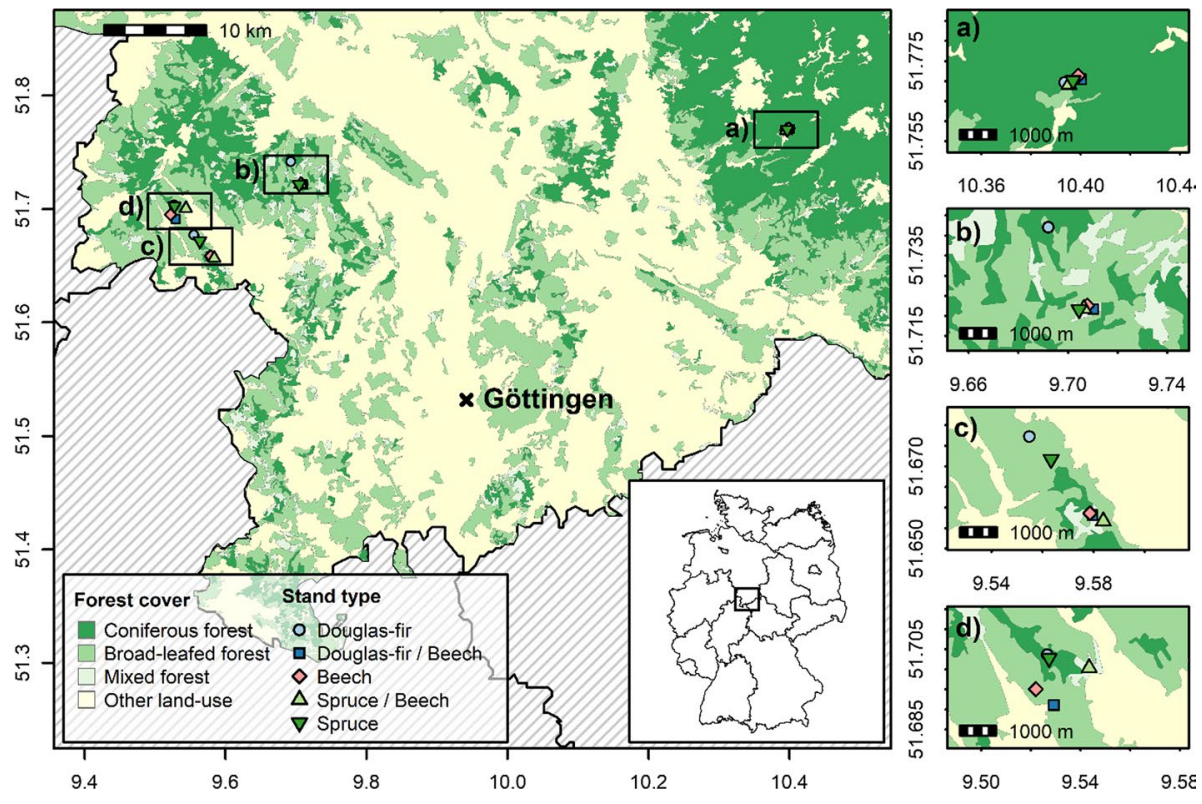

Fig. 1 Location of study sites and study plots in Lower Saxony, Germany. Different symbols correspond to the five different stand types. Background shows forest cover divided in three classes. Forest types and forest cover were taken from Copernicus CORINE Land cover 2018 (EEA 2018). Inset shows Germany with state borders, black rectangle shows study area

depth of $10 \mathrm{~cm}$. Cups were buried flush to soil level and covered with metal mesh (mesh width $1.5 \mathrm{~cm}$ ) to minimize captures of non-target vertebrates. Utilized trapping solution was $150 \mathrm{~mL}$ of a $50 \%$ propylene glycol solution with an added odourless detergent to reduce surface tension. Traps were emptied in three-week intervals, resulting in 1920 total samples. Ground beetles were identified according to Müller-Motzfeld (2006), following the nomenclature used therein.

\section{Functional traits}

We assembled functional traits of ground beetles from published literature and data bases (Table 1) to quantify functional diversity of the ground beetle assemblages. Ten traits were chosen with the aim of characterising differences in habitat use and ecological strategies. When contradictory information was found, information related to populations close to the study area was preferably used, otherwise the most recent source was selected. For species where no data on specific traits were available, data from the next closest relative were used if it seemed plausible, otherwise this trait was left empty (for a complete list of species with their affiliated traits see Table S2 Supplementary Information).

\section{Habitat characteristics}

To identify influences of environmental factors that might drive differences in ground beetle assemblages among forest stand types, we selected nine habitat characteristics that have previously been shown to potentially affect ground beetles. Habitat 


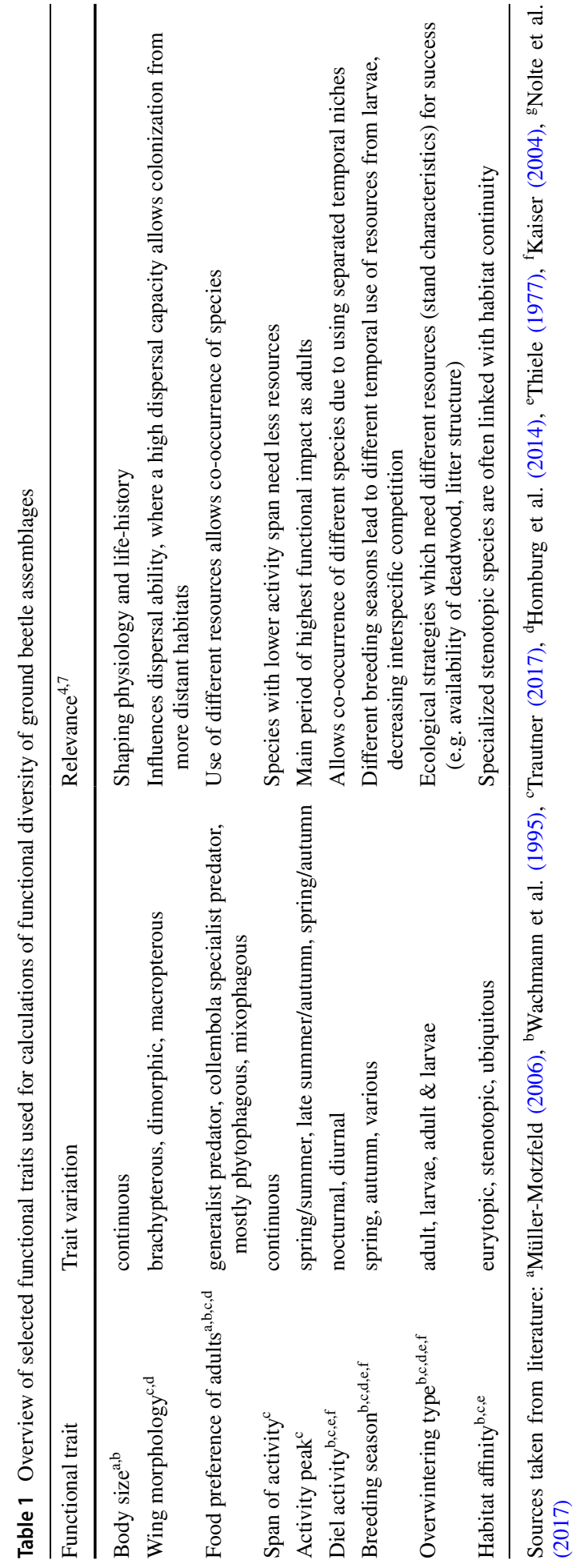


characteristics were: (1) canopy openness, which alters the light regime and therefore also ground temperature and humidity in forests, strongly affecting ground beetle community assemblages (Thiele 1977; Molnár et al. 2001), (2) litter cover, indicating the presence and amount of litter around traps, which alters habitat structure and may provide higher abundance of prey, e.g. for ground beetles preying on collembola (Koivula et al. 1999), (3) litter depth, if increasing, depth provides a more three-dimensional habitat structure that can provide shelter for ground beetles and more niches for potential prey (Pearce et al. 2003), (4) herb cover, impacting microclimatic conditions such as soil moisture and temperature, but compared to canopy cover creating a more smallscale mosaic structure of varying conditions, (5) herb layer structure, which has been shown to impact ground beetles more than species identity, mostly due to altering environmental resistance, affecting mainly forest species which may not be adapted to such conditions (Elek et al. 2001), (6) deadwood cover, indicating the presence of smaller deadwood objects in our study, which, if present in high abundance, can restrict movement of ground beetles due to higher environmental resistance, but can also promote presence of alternative prey, (7) deadwood volume, which provides suitable niches for overwintering and reproduction sites for many ground beetles (Pearce et al. 2003), (8) deadwood decay class, due to varying possibilities of potential prey to colonize deadwood in different decay stages (Andringa et al. 2019) and differences in suitability as habitat for overwintering and (9) soil $\mathrm{pH}$, because many ground beetles show preferences between acidity of the soil (Thiele 1977; Butterfield et al. 1995), and a majority of prey from ground beetles are also sensitive to soil $\mathrm{pH}$, which can further affect abundance and species richness (Elek et al. 2001). Stand age was not included as a variable, as it was dependent on stand type in our study. Measurements of all habitat characteristics besides soil $\mathrm{pH}$ took place in the summer of 2019 across a $10 \mathrm{~m} \times 10 \mathrm{~m}$ grid with traps in the centre of each square.

Deadwood was categorized in fine (branches) and coarse lying deadwood, using $7 \mathrm{~cm}$ diameter at thickest point as a dividing factor. Branch deadwood was quantified using visual cover estimation. Coarse lying deadwood (including tree stumps) were assessed by measuring diameter and length of each piece of dead wood and estimating stage of decay into four classes as suggested by Müller-Using (2005).

Cover estimations (as percent of covered area) were conducted visually for leaf litter and herb layer. To increase precision of estimations the area of each $10 \times 10 \mathrm{~m}$ grid cell was divided into 4 quartiles.

Litter depth was measured along transects at 1,2 and $4 \mathrm{~m}$ distance from each pitfall trap towards each corner of the measurement grid.

Herb layer structure was measured using a vegetation hurdle as described by Mühlenberg (1993). Vertical wire for measurement was set at $3 \mathrm{~cm}$ to include low growing forest vegetation important for ground-active arthropods. Measurements took place in the largest patch of herbaceous vegetation in each quartile of the sampling grid cells.

Canopy openness was recorded at the centre of each trap using a Solariscope (SOL 300, Ing.-Büro Behling, Hermannsburg).

Soil pH was measured between November 2017 and January 2018, using three soil cores (5 cm diameter) from 0 to $5 \mathrm{~cm}$ organic soil (see Lu and Scheu 2020 for details). Seven of the 20 study plots suffered from storm damage and were replaced with closeby alternatives in 2018 (before sampling of ground beetles). Therefore, not all soil pH samples are directly from the studied plots but from surrounding areas of the same stand type. 


\section{Data analysis}

All analyses were carried out in R 3.6.2 (R Core Team 2018). Data was pooled per trap over the complete sampling period and all analyses were conducted on trap level. To ensure we are comparing samples of equal quality and equal completeness we used coverage-based rarefaction curves from incidence frequency data as proposed by Chao and Jost (2012). For this purpose, we used data generated by the iNEXT command from the iNEXT package (Chao et al. 2014). Results showed high percentage of sample coverage for all stand types (Fig. S1 Supplementary Information).

To test for significant differences of environmental variables between stand types we used mean values per trap when multiple measurements were taken around each trap. We used linear mixed-effects models for data on plot level (soil $\mathrm{pH}$ ) and for variables on trap level (canopy openness, litter cover, litter depth, herb cover, herb structure, tree distance, deadwood cover, deadwood volume). Study site (plot-level data) or study plot nested in study site (trap-level data) was added as a random effect to linear mixedeffects models and each environmental variable was tested in a separate model against stand type. We applied multiple comparisons with adjustment of p-values (Bonferroni correction) to the linear model results by a simultaneous inference procedure provided by the glht function in the multcomp package (Hothorn et al. 2008).

For the analyses of ground beetles, we focused on rarefied species richness, abundance and, as a commonly used measure of functional diversity, Rao's quadratic entropy (Rao's Q; Rao, 1982). Rarefied richness was calculated for a specified sample coverage of 0.8 using the estimateD function of the iNEXT package (Chao et al. 2014). Rao's Q, which quantifies the mean dissimilarity in trait values among individuals of an assemblage, was calculated using the $d b F D$ function of the $F D$ package (Laliberte and Legendre 2010). We analysed these response variables in two steps using mixed-effects models with study plot nested in study site as a random effect. In the first step, we fit the mixed models with stand type, north and east coordinates of the study plots and elevation as the fixed effects, to assess the extent to which ground beetle diversity and abundance differed among stand types and geographical regions. Significant differences of response variables between stand types were tested with the glht function in the multcomp package, with adjustment of p-values (Bonferroni correction). In the second step, we replaced stand type by the environmental variables listed above. We chose this approach because not all environmental variables were independent of stand type and therefore collinear. To test for possible collinearity of environmental variables we used vifstep from the usdm package with a threshold of 4 (Naimi et al. 2014). In both steps, the Akaike information criterion (AICc) with small sample correction (Burnham and Anderson 2010) was then used, in a stepwise backward selection of explanatory variables, to select the candidate model with lowest global AICc and thus the largest Akaike weight $\left(\mathrm{w}_{\mathrm{i}}\right)$ as the most supported model. Mixed-effects models were fitted with Gaussian error distribution. Model residual plots were checked for homogeneity of variances and normality (Zuur et al. 2009). For improved model fit, rarefied richness and abundance were log-transformed. 38 pitfall traps were destroyed by wild boars during the course of the study ( $2 \%$ of total samples), with the highest destruction rate taking place in a pure beech plot where 9 traps were destroyed (9\% of samples from this plot). We replaced missing abundance data for individual traps during specific sampling intervals by the mean abundance per trap of the respective plot and sampling period.

To identify indicator species for different stand types we used a multi-level pattern analysis from the indicspecies package (De Cáceres and Legendre 2009) with number 
of permutations set to 999. Moreover, we applied non-metric multidimensional scaling (NMDS) using the function metaMDS in the package vegan (Oksanen et al. 2012) to visualize the differences in assemblage composition of ground beetles between different stand types. Significant environmental variables were fitted to the ordination using the function envfit with 1000 permutations. Furthermore, we used permutational multivariate analysis of variance, provided by the adonis 2 function of the vegan package (Oksanen et al. 2012) for all pairwise combinations of different stand types, and adjusted p-values with Bonferroni correction. We tested for multivariate homogeneity of group dispersions using the betadisper command from the vegan package (Oksanen et al. 2012), with a Bray-Curtis dissimilarity index. Tukey post-hoc test was used to test for significant differences of multiple comparisons of stand types.

To test whether the results are affected by non-forest or vagrant species, all analyses were also carried out with a dataset only containing forest-associated ground beetles (following the definition and list in Müller-Motzfeld 2001). However, the smaller sample set of forest ground beetles did not qualitatively change the results. Therefore, we focus the presentation of the results on the complete data set and present results for forest-associated beetles in the supplementary material (Tables S5- S6 \& Figs S2 - S3 Supplementary Information).

\section{Results}

\section{Environmental conditions}

Litter depth differed significantly among stand types (Table 2). Litter depth was significantly higher in pure beech and mixed stands than in pure coniferous stands, with the only exception of pure spruce compared to beech / Douglas fir mixture where no significant difference could be observed. Herb cover was significantly lower in pure spruce than pure Douglas fir. Pure beech and mixed stands did not show significant variation in comparison to other stand types. The remaining environmental variables showed high variability also within stand types, which made differences among stand types less obvious (Table 2).

Table 2 Comparison of means and standard deviation of measured environmental variables among stand types $(n=48)$

\begin{tabular}{llllll}
\hline & Douglas & Beech / Douglas & Beech & Beech / Spruce & Spruce \\
\hline Canopy openness & $40.7( \pm 17.86)$ & $30.8( \pm 16.13)$ & $33.3( \pm 18.19)$ & $37.4( \pm 18.09)$ & $43.5( \pm 17.47)$ \\
Litter cover & $79.4( \pm 21.56)$ & $92.3( \pm 11.14)$ & $97.4( \pm 3.35)$ & $95.8( \pm 4.02)$ & $81.9( \pm 13.06)$ \\
Litter depth & $2.10( \pm 0.85)^{\mathbf{a}}$ & $3.12( \pm 0.83)^{\mathbf{b c}}$ & $3.65( \pm 0.89)^{\mathbf{b}}$ & $3.67( \pm 0.88)^{\mathbf{b}}$ & $2.41( \pm 0.86)^{\mathbf{a c}}$ \\
Herb cover & $23.8( \pm 19.80)^{\mathbf{a}}$ & $15.6( \pm 12.85)^{\mathbf{a b}}$ & $7.1( \pm 8.24)^{\mathbf{a b}}$ & $8.7( \pm 10.16)^{\mathbf{a b}}$ & $3.6( \pm 5.59)^{\mathbf{b}}$ \\
Herb structure & $7.4( \pm 4.54)$ & $10.0( \pm 10.78)$ & $7.0( \pm 6.39)$ & $6.2( \pm 6.02)$ & $4.4( \pm 4.74)$ \\
Deadwood cover & $4.8( \pm 4.50)$ & $1.6( \pm 0.96)$ & $5.6( \pm 9.41)$ & $2.8( \pm 4.84)$ & $5.4( \pm 4.71)$ \\
Deadwood decay & $2.27( \pm 2.28)$ & $2.27( \pm 0.31)$ & $2.47( \pm 0.37)$ & $2.58( \pm 0.46)$ & $2.46( \pm 0.31)$ \\
Deadwood volume & $0.33( \pm 0.22)$ & $0.26( \pm 0.26)$ & $0.18( \pm 0.14)$ & $0.31( \pm 0.22)$ & $0.26( \pm 0.19)$ \\
Soil-pH & $3.78( \pm 0.73)$ & $3.41( \pm 0.64)$ & $3.39( \pm 0.45)$ & $3.00( \pm 0.29)$ & $3.08( \pm 0.55)$ \\
\hline
\end{tabular}

Superscript letters indicate significant differences among stand types, tested with Tukey's all-pair comparisons test. Results of statistical analyses are only displayed when significant differences were observed 


\section{Ground beetles}

Over the complete sampling period (162 days) a total of 13,164 individuals were collected, belonging to 49 different species from 24 genera (for a complete list of species see Table 4 in Appendix 1). The three most abundant species comprised $62 \%$ of the total catch (Abax parallelepipedus $24.7 \%$, Abax ovalis $20.2 \%$, Pterostichus burmeisteri $17.4 \%$ ). The highest total number of species was found in pure Douglas fir stands (37 species), the lowest number in pure beech and spruce stands (both 29 species). Mixed stands showed intermediate values with 32 (beech / Douglas fir) and 31 (beech / spruce) species. The most abundant species showed higher dominance in pure beech and pure spruce than in other stand types (Fig. 2). The abundance distribution in pure beech also showed noticeably lower evenness among species than other stand types (Fig. 2).

Rarefied richness $(6.22 \pm 0.3 \mathrm{SE})$ and abundance $(96.78 \pm 7.9)$ of ground beetles were highest per plot in pure Douglas fir stands, with significant differences in rarefied richness to pure beech stands $(3.46 \pm 0.1)$ and in abundance to pure spruce $(35.25 \pm 2.6)$ and beech / spruce mixtures (41.21 \pm 2.9$)$ (Fig. 3a,b; Table S4 Supplementary Information). Differences in rarefied richness and abundance of other stand types in pairwise comparisons were non-significant. Functional diversity measured as Rao's Q showed decreasing values from pure Douglas fir $(0.085 \pm 0.003)$ over pure spruce $(0.074 \pm 0.004)$, beech / spruce mixtures $(0.063 \pm 0.003)$, beech / Douglas fir mixtures $(0.060 \pm 0.002)$, to pure beech $(0.045 \pm 0.002)$ (Fig. 3c; Table S4 Supplementary Information).

When replacing stand type by environmental variables in the linear mixed-effects models, mainly litter layer and herb layer characteristics showed significant relationships with ground beetle species richness, abundance and functional diversity (Table 3). While effects of litter cover and litter depth were always negative (Fig. 4b,d,e,f), herb cover showed positive effects (Fig. 4a,c). Increasing herb cover was related to higher rarefied richness and higher abundance of ground beetles. On the contrary an increase in litter cover was correlated with a decline in abundance and functional diversity, while higher litter depth led to lower rarefied richness and lower functional diversity of ground beetles. Furthermore,

Fig. 2 Rank-abundance distribution of ground beetle assemblages of different stand types. Sampling data of study plots of each stand type were pooled and species were ranked according to their relative abundance from high to low. Y-axis is logtransformed and shows relative abundance per species

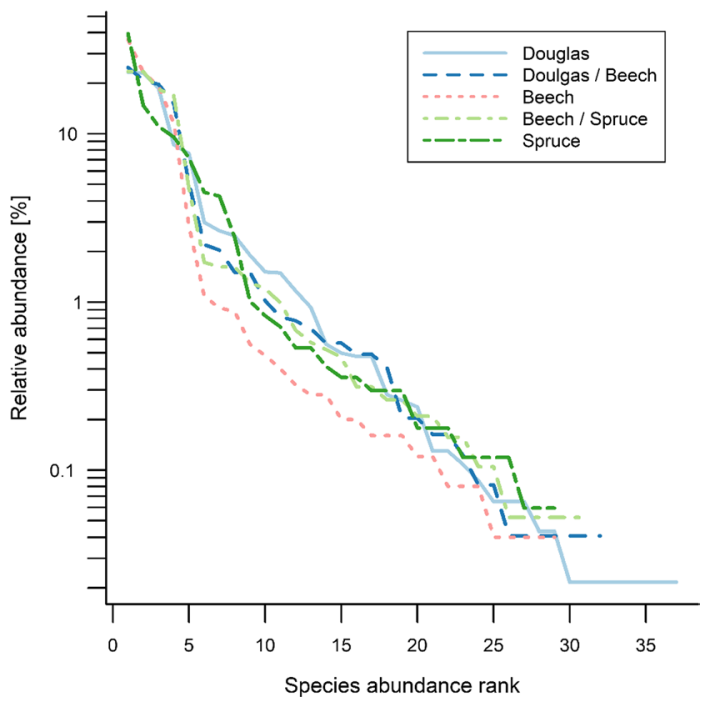


Fig. 3 Effects of stand type on a rarefied richness, $\mathbf{b}$ abundance and $\mathbf{c}$ Rao's Q of ground beetle assemblages on trap level $(n=48)$. Lowercase letters above boxes indicate significant differences among stand types, tested with Tukey's all-pairwise comparisons test. Abbreviations for stand types on x-axis: Do pure Douglas fir, Be/Dobeech / Douglas fir mixture, $B e$ pure beech, $\mathrm{Be} / \mathrm{Sp}$ beech / spruce mixture, $S p$ pure spruce
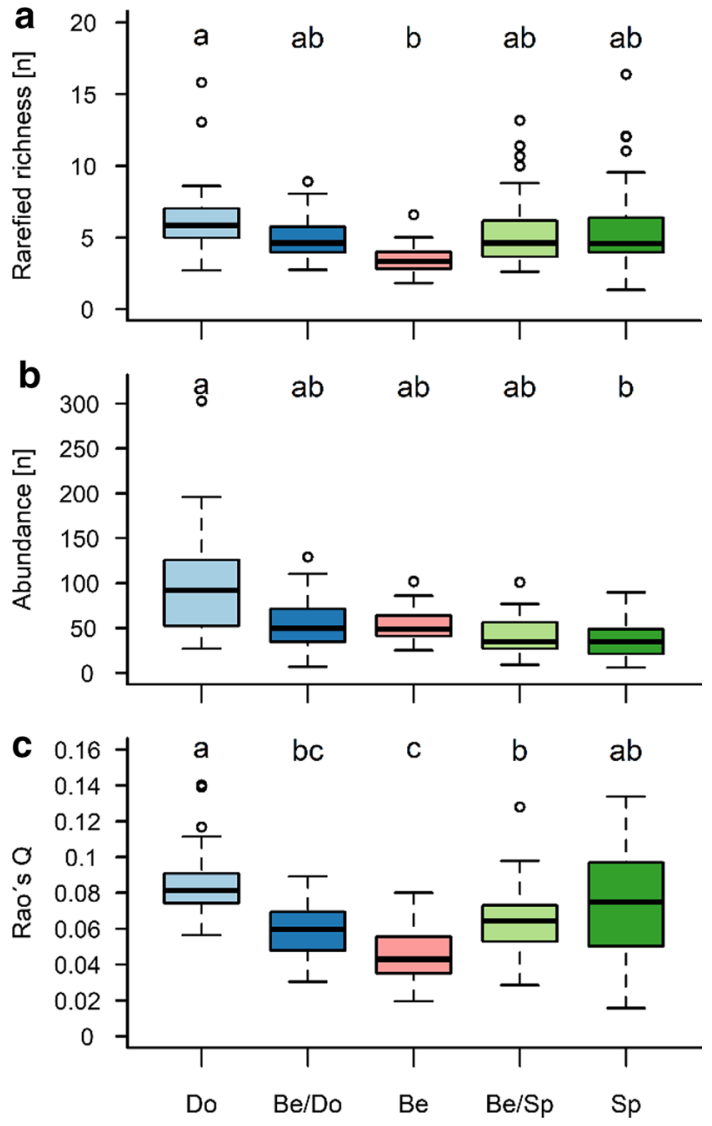

deadwood volume showed significant positive effects on rarefied richness. Other environmental variables, e.g. canopy openness, herb structure and soil-pH showed marginally significant relationships with ground beetles $(\mathrm{p} \leq 0.06$, see Table 3 ).

The composition of the ground beetle species assemblages differed between stand types, with a clear separation of pure stands and intermediate compositions for mixtures in the NMDS ordination (Fig. 5). Coniferous stands (pure Douglas fir and pure spruce) showed a small overlap, but both were clearly separated from pure beech along the first axis of the NMDS. Pairwise permutational multivariate analysis of variance revealed significant differences in species composition between all stand types $(\mathrm{p} \leq 0.03)$, except between mixtures $(p=0.44)$ and between pure beech and beech / Douglas fir mixture $(p=0.06)$ (Table S3 Supplementary Information). Species assemblage composition was significantly more homogenous in pure beech stands compared to all other stand types, likely due to the absence of open habitat generalists, which can appear in other stand types with less canopy closure (Figure S5, Supplementary Information). The overall species composition was related to differences in litter layer, herb layer, deadwood, canopy openness and soil-pH. 
Table 3 Results of the most-supported linear mixed-effects models according to lowest AICc value for a) rarefied richness, b) abundance and c) Rao's Q of ground beetle assemblages

\begin{tabular}{lrrrrr}
\hline Predictor variable & Estimate & Standard error & DF & $t$-value & $p$-value \\
\hline Rarefied richness & & & & & \\
Intercept & 1.5046 & 0.121 & 215 & 12.42 & $<0.001$ \\
Canopy openness & 0.0026 & 0.001 & 215 & 1.97 & 0.051 \\
Herb cover & 0.0084 & 0.002 & 215 & 3.60 & $<0.001$ \\
Deadwood cover & 0.0068 & 0.005 & 215 & 1.48 & 0.140 \\
Deadwood volume & 0.2460 & 0.122 & 215 & 2.02 & 0.045 \\
Litter depth & -0.0843 & 0.030 & 215 & -2.79 & 0.006 \\
Abundance & & & & & \\
Intercept & 1.9338 & 0.656 & 217 & 2.95 & 0.004 \\
Litter cover & 0.0070 & 0.003 & 217 & 2.38 & 0.018 \\
Herb cover & 0.0075 & 0.003 & 217 & 2.47 & 0.014 \\
Herb structure & 0.0096 & 0.005 & 217 & 1.91 & 0.058 \\
Soil-pH & 0.3376 & 0.168 & 18 & 2.01 & 0.060 \\
Rao's Q & & & & & \\
Intercept & 0.1005 & 0.012 & 216 & 8.67 & $<0.001$ \\
Canopy openness & 0.0001 & $<0.001$ & 216 & 1.89 & 0.060 \\
Litter cover & -0.0003 & $<0.001$ & 216 & -2.87 & 0.005 \\
Litter depth & -0.0036 & 0.002 & 216 & -2.31 & 0.022 \\
Herb cover & 0.0002 & $<0.001$ & 216 & 1.50 & 0.134 \\
\hline
\end{tabular}

Pure beech stands showed strong positive correlations with litter depth and litter cover, while they negatively correlated with canopy openness and herb cover. Pure Douglas fir stands were positively correlated with canopy openness. Indicator species analysis confirmed differences between stand types, with two characteristic indicator species for pure beech, one for beech / Douglas fir mixtures and 12 for pure Douglas fir stands (Fig. 5). Pure spruce and beech / spruce mixtures showed no characteristic indicator species.

\section{Discussion}

Our study shows that the effects of non-native tree species on forest biota are not necessarily negative per se, but may rather depend on the group of organism studied. Moreover and, as we discuss below, such effects are related to the developmental stage and the associated environmental conditions of individual forest stands. Main drivers of ground beetle diversity and community structure were environmental factors that are only partially dependent on the specific tree species composition (see also Felipe-Lucia et al. 2018). This indicates that better knowledge of key forest structures that promote biodiversity may also be used to improve the integration of non-native tree species into forest management strategies which are aiming to combine environmental suitability and economic stability under climate change. 

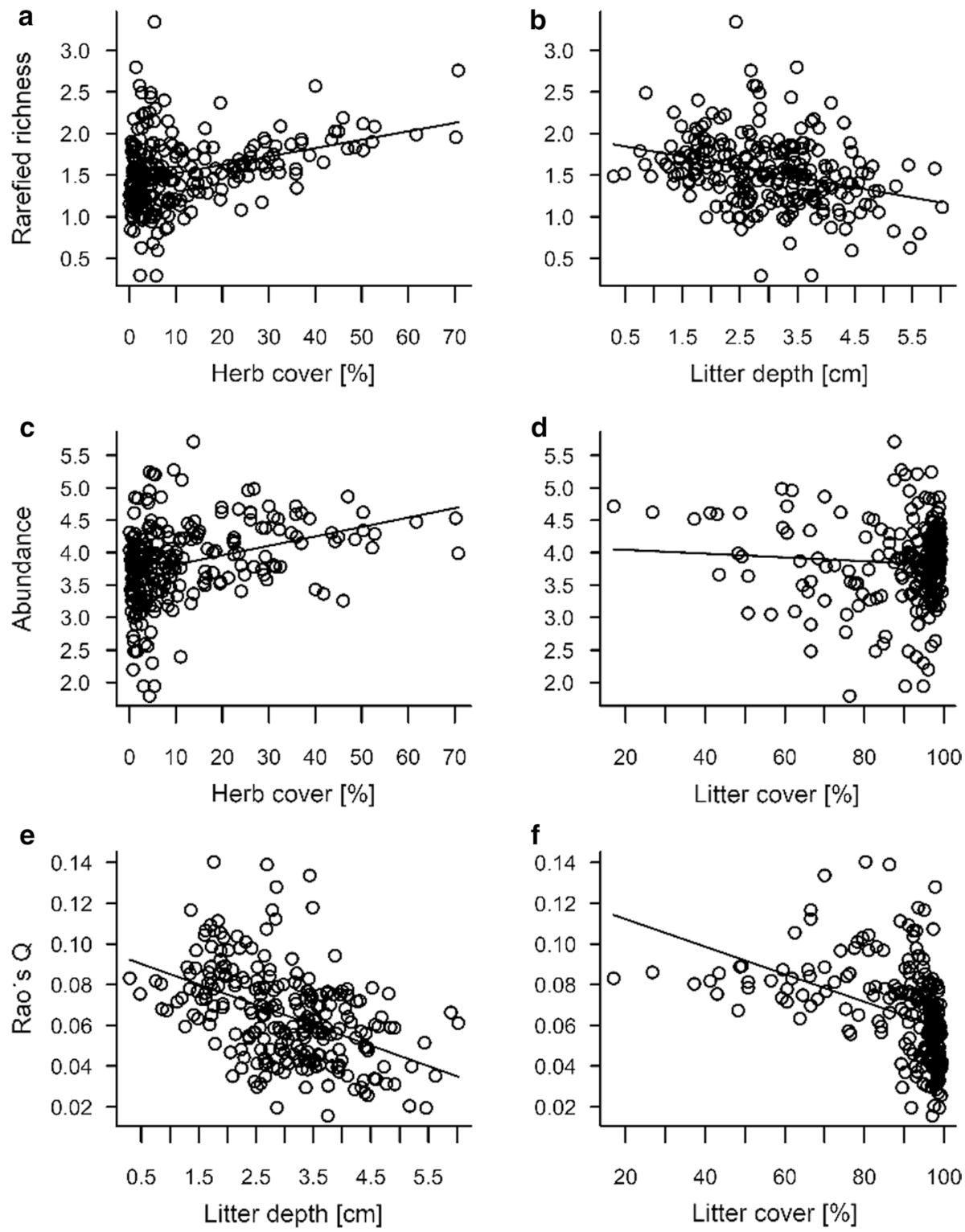

Fig. 4 Relationships of ground beetle rarefied richness (a, b), abundance (c, d), and functional diversity (e, f) with environmental characteristics of the forest stands on trap level $(n=240)$. Regression lines indicate significant $(\mathrm{P} \leq 0.05)$ relationships

\section{Differences among forest types may be modified by forest management}

Contradictory to our hypothesis, rarefied species richness and functional diversity of ground beetles were significantly higher in pure Douglas fir stands compared to pure beech, 


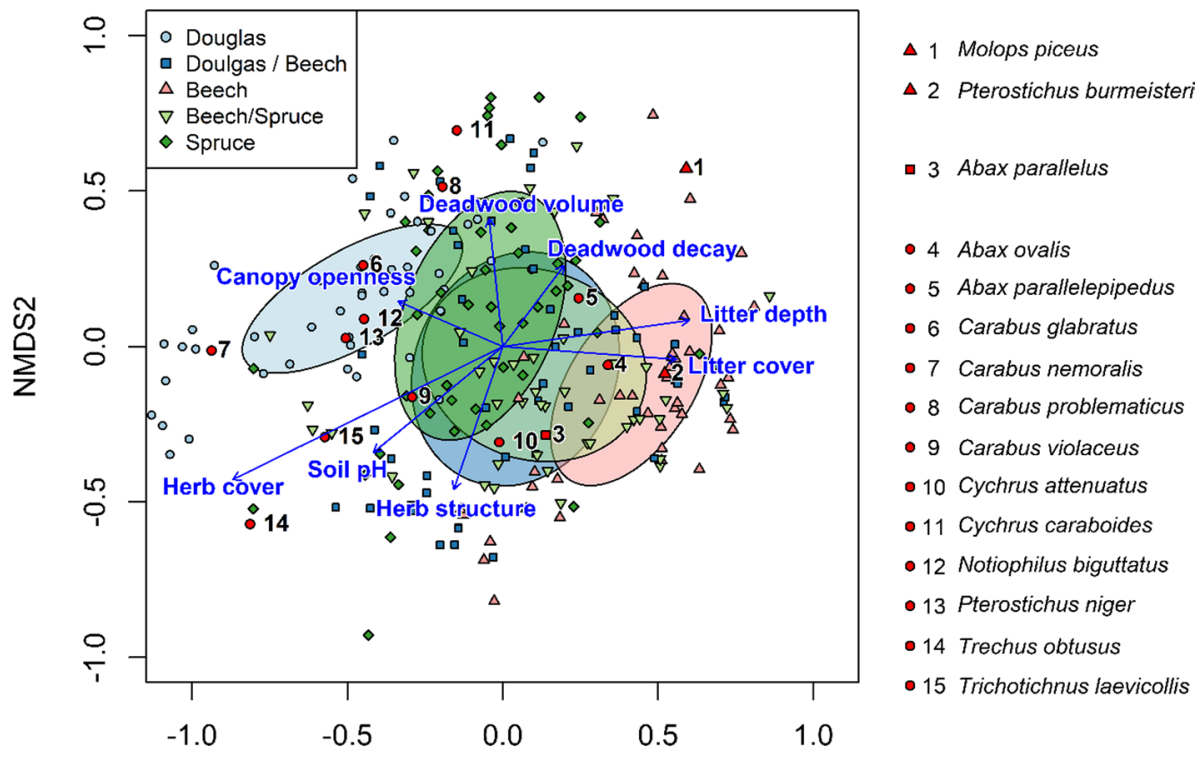

NMDS1

Fig. 5 Non-metric multidimensional scaling of ground beetle assemblages with 240 traps in 5 different stand types. Blue arrows indicate significant environmental effects $(p<0.05)$. Ellipses show standard deviation of stand type point scores. Indicator species according to multi-level pattern analysis are displayed with red symbols corresponding to stand types and are given consecutive numbers (see species list on right hand side)

while differences to pure spruce were statistically insignificant. Furthermore, ground beetle abundance was significantly higher in pure Douglas fir than pure spruce. However, the observed species assemblage composition of ground beetles showed significant differences between all pure stands. Patterns for species richness, functional diversity and abundance can be explained by strong effects of environmental characteristics that varied across the forest stands. Herb cover was highest in pure Douglas fir stands and showed positive correlations with rarefied richness and abundance. While the general influence of herbaceous vegetation on ground beetles has been shown before (Spence and Niemelä 1994; Bortmann 1996; Pakeman and Stockan 2014), it can be argued that this relationship primarily reflects variation of local microsites, e.g. soil water retention and soil $\mathrm{pH}$, as well as light conditions, which are important abiotic factors impacting ground beetle assemblages (Thiele 1977; Magura et al. 2003). In support of this assumption, effects of soil $\mathrm{pH}$ on abundance as well as of canopy openness on rarefied richness and functional diversity were marginally significant, but turned significant when analyses were repeated without herb cover as predictor (data not shown). Importance of soil characteristics, such as soil $\mathrm{pH}$ and soil water retention, on forest ground beetle assemblages has been shown before in studies by Irmler (2001) and Gruttke (2001). Coniferous stands of an intermediate age are often characterized by more open conditions than particularly beech stands of a similar age (Heinrichs et al. 2019). However, these environmental conditions and the consequences for biodiversity can vary across forest developmental stages and tree species. Schuldt and 
Scherer-Lorenzen (2014) found strong negative effects of young Douglas fir stands on spider communities compared to beech and oak, while Finch and Szumelda (2007) found that intermediate-aged Douglas fir plantations substantially altered the composition and diversity of several groups of arthropods, including ground beetles, when compared to oak. This means that an overall evaluation of the effects of non-native tree species, such as Douglas fir, needs to take the full spectrum of forest developmental stages into account. In addition, the size of forest stands may play a role by influencing ground beetle assemblages, as forest ground beetles with strong specialization and limited dispersal abilities may disappear with decreasing stand size and increasing isolation (Gruttke 2001; Irmler 2007). We were not able to test these effects in our study, and future studies should test for interactive effects of forest stand size and tree species composition.

A potential inference that can be drawn from our study is that forest management should try to promote conditions beneficial to associated biota. For ground beetles this could be tolerating or actively creating canopy gaps (see also Butterfield et al. 1995), if this goes along with increasing ground vegetation. Our study showed the significance of higher herb cover in increasing carabid species richness and functional diversity, which can be assumed to be influenced by canopy cover. Such forest structures, with a mosaic pattern of canopy gaps, are a general feature of many older forest stages that are commonly lacking under economically oriented forest management, where harvesting of trees takes place before more diverse forest structures can establish (Hilmers et al. 2018). This also applies to the availability of dead wood (Hunter 1999; Lassauce et al. 2011), which our study indicated to be an important factor for ground beetles as well. Previous studies have shown that dead wood can be an important habitat feature also for non-saproxylic organisms, as it modifies microsite conditions of climate and prey availability (including shelter for overwintering ground beetles; Seibold et al. 2016, Trautner 2017). Features such as light availability (through canopy gaps) and dead wood are not strictly dependent on individual tree species, meaning that forest management could actively utilize these features to improve habitat characteristics for forest biota (see also Felipe-Lucia et al. 2018). This can have implications for the planting of non-native trees in general, where consideration of modifications of the stand structure might help to better connect economic objectives and biodiversity conservation. For a more comprehensive picture, however, more knowledge across multiple taxa and multiple trophic levels is required to develop generalizable recommendations (see also Finch and Szumelda 2007), which should be an incentive for future studies.

\section{Non-native tree species seem to benefit generalist species}

Some of the environmental variables identified to explain differences in ground beetle communities among stand types were inherently associated with the dominant tree species of the forest stands. Therefore, tree species identity still plays an important role in structuring these communities. Notably, characteristics of the litter layer, which depend on the type of tree species-specific litter input (Dickinson and Pugh 1974), showed significant negative effects on all response variables. This finding is in contrast to Koivula et al. (1999) and Magura et al. (2005), who found significantly higher abundances and 
no significant differences in species richness of ground beetles with increased leaf litter amounts in boreal spruce stands in Finland and temperate spruce stands in Hungary. Our results for the effects of litter characteristics on ground beetles were consistent when analyses were repeated with only pure coniferous plots, confirming negative effects also for conifer monocultures (Fig. S4 Supplementary Information). Leaf litter can provide ground beetles with shelter protecting against evaporation and predators (Koivula et al. 1999). It also provides a variety of niches, which are important for numerous other arthropods, favouring a diverse community and therefore providing a higher abundance of prey for ground beetles (Koivula et al. 2002). However, similar to our study, Guillemain, et. al. (1997) found negative effects of litter depth on ground beetle abundance and species richness in a variety of different broadleaf forest stands in France. They attributed these effects to an increase in the proportion of forest specialists and the disappearance of ubiquitous species, which are poorly adapted to living in this environment with respect to locomotory abilities and foraging strategies (see also Finch 2005). In our study, the lower litter depth and litter cover observed for pure Douglas fir might similarly benefit a wider range of more ubiquitous ground beetle species and outweigh positive effects, like provision of shelter, on more specialized forest species. This is reflected in our data by differences in the total abundances of species described as ubiquitous by Müller-Motzfeld (2001), e.g. Pterostichus niger (pure Douglas fir 861; pure beech 22), Carabus nemoralis (pure Douglas fir 54; pure beech 1), when compared to, for example, the mountainous forest specialist Pterostichus burmeisteri (pure Douglas fir 138; pure beech 909). A loss of forest specialist and therefore a shift in species assemblages was also discussed before for several other arthropod taxa in Douglas fir stands (Kohlert and Roth 2000; Winter 2001; Goßner and Ammer 2006). Repeating our analyses with a reduced subset of only strict forest species of ground beetles showed a lower influence of litter layer, supporting the assumption that effects of litter layer are predominantly influencing non-forest ground beetles. In terms of biodiversity conservation, this means that Douglas fir plantations may not provide secondary habitat for more specialized species associated with native beech forests. This finding is further supported by the strongly deviating species composition of beech and Douglas fir stands revealed by NMDS analysis (and which also applies to stands of Norway spruce in our study; see also Finch 2005). On the other hand, high functional diversity of ground beetles in pure coniferous stands suggests that these stands may provide a suitable habitat for a wide range of functionally different ground-beetle species, which can contribute to biodiversity conservation in general (although not necessarily to conservation of the specific biodiversity of native forests).

\section{Mixed-species stands with trade-offs for biodiversity}

Mixing non-native with native tree species might be an option to improve both the conservation of typical biodiversity of native forests and economic yields under climate change. In our study, ground beetle species composition of the mixed stands was a mixture of the 
beetle composition of pure stands. This indicates that forest stands composed of non-native and native tree species can retain more of the typical associated forest species than pure stands of non-native trees. However, tree mixtures in our study also showed intermediate values for abundance and diversity, meaning that mixture effects were not additive and apparently did not lead to an increased availability of niches that would allow for the coexistence of the full set of species associated with coniferous and deciduous forest stands. These patterns can have implications for forest management at larger spatial scales. A previous study indicated that small-scale heterogeneity (such as created by mixtures of tree species in our study) of forest stands might lead to lower increases of regional diversity in several taxa than heterogeneity at larger scales (at the cost of more uniformity at smaller scales, such as monoculture stands in our study; Schall et al. 2018). Similarly, Heinrichs et al. (2019) found for plants and lichens, that stand-level mixtures do not necessarily promote landscape-level diversity. These findings suggest that the spatial scale at which mixing tree species and creating habitat heterogeneity takes place is a key research topic when it comes to developing sustainable management strategies. Future studies should take this into account also when evaluating the effects of non-native tree species on biodiversity, as such patterns might be tree species-specific (Heinrichs et al. 2019).

\section{Conclusions}

Overall, our study highlights that not all drivers of ground beetle abundance and diversity are dependent on tree species identity. Therefore, negative effects of integrating non-native tree species in forests could be mitigated by forest management strategies, e.g. by increasing deadwood amounts or promoting canopy gaps. However, our results indicate that generalist species might benefit more from such measures than more specialized species adapted to the specific environmental conditions of native forests. Thus, achieving high levels of species richness in forests containing non-native tree species does not necessarily mean that these forests can preserve native biodiversity and species composition to full extents. This problem might be alleviated to some extent by planting non-natives in mixtures with native tree species, but our study and previous research indicates that the spatial scale at which such mixing is implemented can strongly influence biodiversity patterns beyond the local scale of individual forest stands. The contrasting findings of our and previous studies with respect to the influence of Douglas fir on associated biota, which may in part be due to taxon-specific responses and shifts in environmental effects over the course of forest development, highlights that a clear understanding of the ecological consequences of planting non-native tree species will strongly benefit from more research aimed at integrating multiple taxa and multiple forest developmental stages. 


\section{Appendix 1}

Table 4 Complete list of species with abundances per stand type as well as total abundance per species and per stand type

\begin{tabular}{|c|c|c|c|c|c|c|}
\hline \multirow[t]{2}{*}{ Species } & \multicolumn{5}{|l|}{ Stand type } & \multirow[t]{2}{*}{ Total } \\
\hline & Douglas fir & $\begin{array}{l}\text { Beech / } \\
\text { Douglas } \\
\text { fir }\end{array}$ & Beech & Beechs / Spruce & Spruce & \\
\hline Abax ovalis & 1063 & 513 & 477 & 352 & 248 & 2653 \\
\hline Abax parallelepipedus & 1077 & 483 & 578 & 449 & 663 & 3250 \\
\hline Abax parallelus & 3 & 37 & 4 & 2 & 5 & 51 \\
\hline Amara ovata & 12 & 14 & 3 & 10 & 12 & 51 \\
\hline Asaphidion flavipes & 1 & 0 & 0 & 0 & 0 & 1 \\
\hline Asaphidion pallipes & 0 & 1 & 0 & 0 & 0 & 1 \\
\hline Badister lacertosus & 0 & 5 & 2 & 1 & 0 & 8 \\
\hline Bembidion deletum & 4 & 1 & 0 & 0 & 2 & 7 \\
\hline Bembidion lampros & 1 & 0 & 5 & 0 & 0 & 6 \\
\hline Bembidion nigricorne & 0 & 3 & 0 & 0 & 0 & 3 \\
\hline Calathus rotundicollis & 2 & 0 & 0 & 2 & 0 & 4 \\
\hline Carabus auratus & 0 & 0 & 1 & 0 & 0 & 1 \\
\hline Carabus auronitens & 69 & 37 & 27 & 91 & 41 & 265 \\
\hline Carabus coriaceus & 0 & 1 & 0 & 1 & 0 & 2 \\
\hline Carabus glabratus & 88 & 20 & 1 & 4 & 6 & 119 \\
\hline Carabus nemoralis & 54 & 0 & 1 & 3 & 5 & 63 \\
\hline Carabus problematicus & 353 & 54 & 8 & 23 & 121 & 559 \\
\hline Carabus sylvestris & 3 & 0 & 0 & 0 & 0 & 3 \\
\hline Carabus violaceus & 123 & 50 & 23 & 31 & 14 & 241 \\
\hline Cychrus attenuatus & 43 & 12 & 12 & 25 & 9 & 101 \\
\hline Cychrus caraboides & 70 & 25 & 5 & 6 & 5 & 111 \\
\hline Diachromus germanus & 0 & 1 & 0 & 3 & 1 & 5 \\
\hline Dromius agilis & 0 & 0 & 0 & 0 & 1 & 1 \\
\hline Dromius fenestratus & 1 & 0 & 0 & 0 & 0 & 1 \\
\hline Harpalus affinis & 1 & 0 & 0 & 0 & 0 & 1 \\
\hline Harpalus laevipes & 6 & 4 & 4 & 1 & 3 & 18 \\
\hline Harpalus latus & 22 & 10 & 14 & 13 & 3 & 62 \\
\hline Harpalus rufipes & 1 & 0 & 0 & 0 & 0 & 1 \\
\hline Harpalus signaticornis & 1 & 0 & 0 & 0 & 0 & 1 \\
\hline Leistus rufomarginatus & 5 & 1 & 1 & 1 & 0 & 8 \\
\hline Limnodromus assimilis & 13 & 17 & 0 & 6 & 2 & 38 \\
\hline Loricera pilicornis & 0 & 1 & 0 & 0 & 0 & 1 \\
\hline Molops piceus & 23 & 14 & 71 & 9 & 7 & 124 \\
\hline Nebria brevicollis & 22 & 2 & 7 & 5 & 2 & 38 \\
\hline Nebria salina & 0 & 0 & 0 & 4 & 3 & 7 \\
\hline Notiophilus biguttatus & 115 & 19 & 3 & 31 & 72 & 240 \\
\hline Notiophilus germinyi & 0 & 0 & 0 & 1 & 1 & 2 \\
\hline Notiophilus rufipes & 1 & 0 & 0 & 1 & 2 & 4 \\
\hline
\end{tabular}


Table 4 (continued)

\begin{tabular}{lcrrrrr}
\hline Species & \multicolumn{2}{l}{ Stand type } & & & Total \\
\cline { 2 - 6 } & Douglas fir & $\begin{array}{l}\text { Beech / } \\
\text { Douglas } \\
\text { fir }\end{array}$ & Beech & Beechs / Spruce & Spruce \\
& & & & \\
\hline Poecilus cupreus & 6 & 5 & 7 & 5 & 6 & 29 \\
Poecilus versicolor & 0 & 1 & 0 & 0 & 0 & 1 \\
Pterostichus aethiops & 2 & 4 & 2 & 19 & 17 & 44 \\
Pterostichus burmeisteri & 138 & 608 & 909 & 448 & 186 & 2289 \\
Pterostichus niger & 861 & 124 & 22 & 33 & 76 & 1116 \\
Pterostichus oblongopunctatus & 399 & 371 & 288 & 322 & 161 & 1541 \\
Pterostichus strenuus & 3 & 0 & 2 & 0 & 0 & 5 \\
Stenolophus teutonus & 1 & 0 & 0 & 0 & 0 & 1 \\
Trechus obtusus & 11 & 2 & 4 & 0 & 0 & 17 \\
Trichotichnus laevicollis & 26 & 12 & 10 & 11 & 9 & 68 \\
Zabrus tenebroides & 0 & 0 & 1 & 0 & 0 & 1 \\
Total & 4624 & 2452 & 2492 & 1913 & 1683 & 13,164 \\
\hline
\end{tabular}

Supplementary Information The online version contains supplementary material available at https://doi. org/10.1007/s10531-021-02155-1.

Acknowledgements We thank Christian Ammer, Serena Müller, Jonas Glatthorn, all members of the RTG 2300 consortium and the local foresters who coordinated and helped with the establishment and maintenance of the project. This work was supported by Deutsche Forschungsgemeinschaft (DFG, German Research Foundation)_-316045089/GRK2300.

Authors' contributions AS conceived the research, PK and DM collected the data, PK processed and analysed the data, PK drafted the initial version of the manuscript and all authors substantially contributed to later versions of the manuscript. All authors gave final approval for publication.

Funding Open Access funding enabled and organized by Projekt DEAL. This work was funded by Deutsche Forschungsgemeinschaft (DFG, German Research Foundation) - 316045089/GRK2300.

Data availability Data will be made available at https://www.bexis.uni-jena.de/Login/Account.aspx upon publication.

Code availability Not applicable.

\section{Compliance with ethical standards}

Conflict of interest The authors declare that they have no conflict of interest.

Open Access This article is licensed under a Creative Commons Attribution 4.0 International License, which permits use, sharing, adaptation, distribution and reproduction in any medium or format, as long as you give appropriate credit to the original author(s) and the source, provide a link to the Creative Commons licence, and indicate if changes were made. The images or other third party material in this article are included in the article's Creative Commons licence, unless indicated otherwise in a credit line to the material. If material is not included in the article's Creative Commons licence and your intended use is not permitted by statutory regulation or exceeds the permitted use, you will need to obtain permission directly from the copyright holder. To view a copy of this licence, visit http://creativecommons.org/licenses/by/4.0/. 


\section{References}

Ammer C (2019) Diversity and forest productivity in a changing climate. New Phytol 221:50-66. https://doi. org/10.1111/nph.15263

Ampoorter E, Barbaro L, Jactel H et al (2020) Tree diversity is key for promoting the diversity and abundance of forest-associated taxa in Europe. Oikos 129:133-146. https://doi.org/10.1111/oik.06290

Andringa JI, Zuo J, Berg MP et al (2019) Combining tree species and decay stages to increase invertebrate diversity in dead wood. For Ecol Manage 441:80-88. https://doi.org/10.1016/j.foreco.2019.03.029

Barsoum N, Fuller L, Ashwood F et al (2014) Ground-dwelling spider (Araneae) and carabid beetle (Coleoptera: Carabidae) community assemblages in mixed and monoculture stands of oak (Quercus robur L./Quercus petraea (Matt.) Liebl.) and Scots pine (Pinus sylvestris L.). For Ecol Manage 321:29_ 41. https://doi.org/10.1016/j.foreco.2013.08.063

Bindewald A, Michiels H-G, Bauhus J (2019) Risk is in the eye of the assessor: comparing risk assessments of four non-native tree species in Germany. For An Int J For Res. https://doi.org/10.1093/fores try/cpz052

Borrass L, Kleinschmit D, Winkel G (2017) The "German model" of integrative multifunctional forest management-Analysing the emergence and political evolution of a forest management concept. For Policy Econ 77:16-23. https://doi.org/10.1016/j.forpol.2016.06.028

Bortmann I (1996) Heterogenität der Besiedelung durch Laufkäfer (Col: Carabidae) in einem Buchenwald. Faun Mitteilungen Supplement:87-126

Burnham KP, Anderson DR (2010) Model selection and multimodel inference: A practical informationtheoretic approach, 2nd edn. Springer, New York

Butterfield J, Luff ML, Baines M, Eyre MD (1995) Carabid beetle communities as indicators of conservation potential in upland forests. For Ecol Manage 79:63-77. https://doi.org/10.1016/0378-1127(95) $03620-2$

Cameron KH, Leather SR (2012) How good are carabid beetles (Coleoptera, Carabidae) as indicators of invertebrate abundance and order richness? Biodivers Conserv 21:763-779. https://doi.org/10.1007/s10531-011-0215-9

Cardinale BJ, Duffy JE, Gonzalez A et al (2012) Biodiversity loss and its impact on humanity. Nature 486:59-67. https://doi.org/10.1038/nature11148

Chao A, Gotelli NJ, Hsieh TC et al (2014) Rarefaction and extrapolation with Hill numbers: A framework for sampling and estimation in species diversity studies. Ecol Monogr 84:45-67. https://doi. org/10.1890/13-0133.1

Chao A, Jost L (2012) Coverage-based rarefaction and extrapolation: Standardizing samples by completeness rather than size. Ecology 93:2533-2547. https://doi.org/10.1890/11-1952.1

De Cáceres M, Legendre P (2020) Relationship between species and groups of sites. Ecol Packag. https://doi.org/10.1890/08-1823.1

Dickinson CH, Pugh GJF (1974) Biology of Plant Litter Decomposition. Academic Press

Dirzo R, Young HS, Galetti M et al (2014) Defaunation in the Anthropocene. Science (80-) 345:401406. https://doi.org/10.1126/science. 1251817

DWD (2018) data from: https://www.dwd.de/DE/leistungen/klimadatendeutschland, last accessed: 20.10.2018

EEA (2018) Corine Land Cover. In: Eur. Union, Copernicus L. Monit. Serv. https://land.copernicus.eu/ pan-european/corine-land-cover/clc2018.

Elek Z, Magura T, Tóthmérész B (2001) Impacts of non-native Norway spruce plantation on abundance and species richness of ground beetles (Coleoptera: Carabidae). Web Ecol 2:32-37. https://doi.org/ 10.5194/we-2-32-2001

Felipe-Lucia MR, Soliveres S, Penone C et al (2018) Multiple forest attributes underpin the supply of multiple ecosystem services. Nat Commun. https://doi.org/10.1038/s41467-018-07082-4

Finch OD (2005) Evaluation of mature conifer plantations as secondary habitat for epigeic forest arthropods (Coleoptera: Carabidae; Araneae). For Ecol Manage 204:23-36. https://doi.org/10.1016/j. foreco.2004.07.071

Finch OD, Szumelda A (2007) Introduction of Douglas fir (Pseudotsuga menziesii (Mirb.) Franco) into Western Europe: Epigaeic arthropods in intermediate-aged pure stands in northwestern Germany. For Ecol Manage 242:260-272. https://doi.org/10.1016/j.foreco.2007.01.039

Gallé R, Szabó Á, Császár P, Torma A (2018) Spider assemblage structure and functional diversity patterns of natural forest steppes and exotic forest plantations. For Ecol Manage 411:234-239. https:// doi.org/10.1016/j.foreco.2018.01.040

Goßner M, Ammer U (2006) The effects of Douglas-fir on tree-specific arthropod communities in mixed species stands with European beech and Norway spruce. Eur J For Res 125:221-235. https://doi. org/10.1007/s 10342-006-0113-y 
Gossner M, Simon U (2002) Introduced Douglas fir (Pseudotsuga menziesii (Mirb.) Franco) affects community structure of tree-crown dwelling beetles in a managed European forest. In: Kowarik I, Starfinger U (eds) Biologische Invasionen-eine Herausforderung zum Handeln? NEOBIOTA 1. pp 167-179

Gossner M, Utschick H (2004) Douglas fir stands deprive overwintering bird species of food resource. Neobiota 3:105-122

Gruttke H (2001) Welche Bedeutung haben Habitatgröße und -isolation für das Vorkommen waldtypischer Laufkäfer in Waldrelikten und Kleingehölzen einer Agrarlandschaft? Angew Carabidologie Suppl II:81-98

Guillemain M, Loreau M, Daufresne T (1997) Relationships between the regional distribution of carabid beetles and the abundance of their potential prey. Acta Oecologica 18:465-482

Gustafsson L, Bauhus J, Asbeck T et al (2020) Retention as an integrated biodiversity conservation approach for continuous-cover forestry in Europe. Ambio 49:85-97. https://doi.org/10.1007/ s13280-019-01190-1

Hallmann CA, Sorg M, Jongejans E et al (2017) More than 75 percent decline over 27 years in total flying insect biomass in protected areas. PLoS ONE. https://doi.org/10.1371/journal.pone.0185809

Heinrichs S, Ammer C, Mund M et al (2019) Landscape-scale mixtures of tree species are more effective than stand-scale mixtures for biodiversity of vascular plants, bryophytes and lichens. Forests 10:1-35

Hilmers T, Friess N, Bässler C et al (2018) Biodiversity along temperate forest succession. J Appl Ecol 55:2756-2766. https://doi.org/10.1111/1365-2664.13238

Homburg K, Homburg N, Schäfer F et al (2014) Carabids.org - a dynamic online database of ground beetle species traits (Coleoptera, Carabidae). Insect Conserv Divers 7:195-205. https://doi.org/10.1111/icad.12045

Hothorn T, Bretz F, Westfall P (2008) Simultaneous inference in general parametric models. Biometrical J 50:346-363. https://doi.org/10.1002/bimj.200810425

Hunter ML (ed) (1999) Maintaining Biodiversity in Forest Ecosystems. Cambridge University Press

Irmler U (2001) Charakterisierung der Laufkäfergemeinschaften schleswig-holsteinischer Wälder und Möglichkeiten ihrer ökologischen Bewertung. Angew Carabidologie Suppl II:21-32

Irmler U (2007) Die Laufkäfer kleiner Wälder in Schleswig-Holstein. Angew Carabidol 8:1-8

Irwin S, Pedley SM, Coote L et al (2014) The value of plantation forests for plant, invertebrate and bird diversity and the potential for cross-taxon surrogacy. Biodivers Conserv 23:697-714. https://doi. org/10.1007/s 10531-014-0627-4

Kaiser M (2004) Faunistik und biogeographie der anisodactylinae und harpalinae westfalens (Coleoptera: Carabidae). Abhandlungen aus dem Westfälischen Museum für Naturkd 66:155

Kennedy CEJ, Southwood TRE (1984) The number of species of insects associated with british trees: a re-analysis. J Anim Ecol 53:455-478

van Klink R, Bowler DE, Gongalsky KB et al (2020) Meta-analysis reveals declines in terrestrial but increases in freshwater insect abundances. Science (80-) 368:417-420. https://doi.org/10.1126/ SCIENCE.AAX9931

Kohlert A, Roth M (2000) Der Einfluß fremdländischer Baumarten (Douglasie: Pseudotsuga menziesii) auf saprophage Arthropoden und epigäische Regulatoren. MittDtschGesAllgAngewEnt 12:71-74

Koivula M, Kukkonen J, Niemelä J (2002) Boreal carabid-beetle (Coleoptera, Carabidae) assemblages along the clear-cut originated succession gradient. Biodivers Conserv 11:1269-1288

Koivula M, Punttila P, Haila Y, Niemelä J (1999) Leaf litter and the small-scale distribution of carabid beetles (Coleoptera, Carabidae) in the boreal forest. Ecography (Cop) 22:424-435

Laliberte E, Legendre P (2010) A distance-based framework for measuring functional diversity from multiple traits. Ecology 91:299-305. https://doi.org/10.1890/08-2244.1

Lassauce A, Paillet Y, Jactel H, Bouget C (2011) Deadwood as a surrogate for forest biodiversity: Metaanalysis of correlations between deadwood volume and species richness of saproxylic organisms. Ecol Indic 11:1027-1039. https://doi.org/10.1016/j.ecolind.2011.02.004

Lu J-Z, Scheu S (2020) Mixing conifers and deciduous trees (Fagus sylvatica): response of soil microorganisms. BioRxiv Prepr. https://doi.org/10.1101/2020.07.21.213900

Magura T, Tóthmérész B, Elek Z (2003) Diversity and composition of carabids during a forestry cycle. Biodivers Conserv 12:73-85

Magura T, Tóthmérész B, Elek Z (2005) Impacts of leaf-litter addition on carabids in a conifer plantation. Biodivers Conserv 14:475-491. https://doi.org/10.1007/s10531-004-7307-8

Martello F, De Bello F, De Castro Morini MS et al (2018) Homogenization and impoverishment of taxonomic and functional diversity of ants in Eucalyptus plantations. Sci Rep 8:1-11. https://doi.org/10. 1038/s41598-018-20823-1 
Matevski D, Schuldt A (2020) Tree species richness, tree identity and non-native tree proportion affect arboreal spider diversity, abundance and biomass. For Ecol Manage (in press). https://doi.org/10. 1016/j.foreco.2020.118775

Molnár T, Magura T, Tóthmérész B, Elek Z (2001) Ground beetles (Carabidae) and edge effect in oakhornbeam forest and grassland transects. Eur J Soil Biol 37:297-300. https://doi.org/10.1016/ S1164-5563(01)01103-7

Mühlenberg M (1993) Freilandökologie, 3. Quelle \& Meyer, Heidelberg u. Wiesbaden, Edition

Müller-Motzfeld G (2004) Käfer Mitteleuropas, Bd. 2: Adephaga I: Carabidae. In: Freude H, Harde KW, Lohse GA, Klasunitzer B (eds) Käfer Mitteleuropas, Bd. 2: Adephaga I: Carabidae. Spektrum-Verlag, p 521

Müller-Motzfeld G (2001) Laufkäfer in den Wäldern Deutschlands. Angew Carabidologie Suppl II:9-20

Müller-Using S (2005) Totholzdynamik eines Buchenbestandes im Solling. Berichte des Forschungszentrum Waldökosysteme Univ Göttingen 193:

Naimi B, Hamm NAS, Groen TA et al (2014) Where is positional uncertainty a problem for species distribution modelling? Ecography (Cop) 37:191-203. https://doi.org/10.1111/j.1600-0587.2013. 00205.x

NIBIS (2018) data from: https://nibis.lbeg.de/cardomap3, last accessed: 15.10.2018

Nolte D, Schuldt A, Gossner MM et al (2017) Functional traits drive ground beetle community structures in Central European forests: Implications for conservation. Biol Conserv 213:5-12. https:// doi.org/10.1016/j.biocon.2017.06.038

Oksanen AJ, Blanchet FG, Kindt R et al (2012) Community Ecology Package. Ecol Packag doi 10(4135/9781412971874):n145

Oxbrough A, García-Tejero S, Spence J, O’Halloran J (2016) Can mixed stands of native and nonnative tree species enhance diversity of epigaeic arthropods in plantation forests? For Ecol Manage 367:21-29. https://doi.org/10.1016/j.foreco.2016.02.023

Pakeman RJ, Stockan JA (2014) Drivers of carabid functional diversity: Abiotic environment, plant functional traits, or plant functional diversity? Ecology 95:1213-1224. https://doi.org/10.1890/ 13-1059.1

Pearce JL, Venier LA, McKee J et al (2003) Influence of habitat and microhabitat on carabid (Coleoptera: Carabidae) assemblages in four stand types. Can Entomol 135:337-357. https://doi.org/10.4039/n02-031

R Core Team (2018) R: A language and environment for statistical computing. R Foundation for Statistical Computing, Vienna, Austria. https://www.r-project.org/.

Rao R (1982) Diversity and dissimilarity. Theor Popul Biol 21:24-43

Rosenberg KV, Dokter AM, Blancher PJ et al (2019) Decline of the North American avifauna. Science 366:120-124. https://doi.org/10.1126/science.aaw1313

Schall P, Gossner MM, Heinrichs S et al (2018) The impact of even-aged and uneven-aged forest management on regional biodiversity of multiple taxa in European beech forests. J Appl Ecol 55:267-278. https://doi.org/10. $1111 / 1365-2664.12950$

Schmid M, Pautasso M, Holdenrieder O (2014) Ecological consequences of Douglas fir (Pseudotsuga menziesii) cultivation in Europe. Eur J For Res 133:13-29. https://doi.org/10.1007/s10342-013-0745-7

Schuldt A, Scherer-Lorenzen M (2014) Non-native tree species (Pseudotsuga menziesii) strongly decreases predator biomass and abundance in mixed-species plantations of a tree diversity experiment. For Ecol Manage. https://doi.org/10.1016/j.foreco.2014.04.036

Seibold S, Bässler C, Baldrian P et al (2016) Dead-wood addition promotes non-saproxylic epigeal arthropods but effects are mediated by canopy openness. Biol Conserv 204:181-188. https://doi.org/10.1016/j.biocon.2016. 09.031

Seibold S, Gossner MM, Simons NK et al (2019) Arthropod decline in grasslands and forests is associated with landscape-level drivers. Nature 574:671-674. https://doi.org/10.1038/s41586-019-1684-3

Spence JR, Niemelä J (1994) Sampling carabid assemblages with pitfall traps: The madness and the method. Can Entomol 126:881-894. https://doi.org/10.4039/Ent126881-3

Thiele H-U (1977) Carabid Beetles in Their Environments - A Study on Habitat Selection by Adaptations in Physiology and Behaviour. Springer-Verlag, Berlin Heidelberg

Trautner J (2017) Die Laufkäfer Baden-Württembergs. Verlag Eugen Ulmer, Stuttgart

Wachmann E, Platen R, Barndt D (1995) Laufkäfer - Beobachtung Lebensweise, 1. Naturbuch Verlag, Augsburg

Winter K (2001) Zur Arthropodenfauna in niedersächsischen Douglasienforsten I. Reinbestände in der Ostheide und im Solling. Forst und Holz 56:355-363

Zuur AF, Ieno EN, Walker N et al (2009) Mixed effects models and extensions in ecology with R. Springer, New York, New York, NY

Publisher's Note Springer Nature remains neutral with regard to jurisdictional claims in published maps and institutional affiliations. 